\section{Is non-industrial society undergoing an energy balance transition predisposed to accumulate abdominal adipose tissue and susceptible to knee osteoarthritis?}

We read with deep interest a recent article published in this journal by lan Wallace et al, ${ }^{1}$ who found that individuals born under conditions of energetic scarcity who later encounter greater energy abundance are predisposed to accumulate abdominal adipose tissue, making them susceptible to knee osteoarthritis (OA) at lower levels of body mass index (BMI). We really appreciate the work which was done by the authors. However, some worthwhile issues need to be explored.

First, one of the major findings by the authors was that individuals in non-industrial societies undergoing an energy balance transition are inclined to accumulate abdominal adipose tissue and tend to have 'low-BMI, large-abdomen phenotype'. We fully agree with the authors that the Tarahumara had lower BMI compared with the Framingham, as evidence showed in figure 2A. ${ }^{1}$ However, figure $2 \mathrm{~B},{ }^{1}$ the comparison of abdomen sizes in a given weight, was unable to prove that the Tarahumara had a large-abdomen phenotype, and instead, we think a density plot of abdomen size would help to define this issue more convincingly. On the other hand, the differences in abdomen size between Tarahumara and Framingham exhibited in figure $2 \mathrm{~B}^{1}$ could result from the differences in height between the two peoples. Whether or not having experienced energy balance transition, a short person is more likely to have a larger abdomen size than a tall person in a given weight. Additionally, the authors failed to collect data from Tarahumara women, which might lead to overestimation of abdomen size of the Tarahumara, considering that men and women tend to have different fat deposit locations when gaining weight. Overall, by data of this study, it might be not appropriate to conclude that the Tarahumara are predisposed to accumulate abdominal adipose tissue.

Second, the authors did not mention the unexpected negative correlation between probability of knee OA and abdomen size in the Framingham, which was showed in figure $3 \mathrm{C}, \mathrm{F}^{1}$ Given the known strong association with obesity and knee $\mathrm{OA}^{2}$ it is more likely that rising abdomen size will lead to an increase in OA prevalence.

Third, the authors emphasised the contribution of chronic low-grade systemic inflammation to knee OA pathogenesis in the Tarahumara. However, according to the previous study, surrogates for mechanical stress were suggested to be the most important risk factors for OA in weight-bearing joints. ${ }^{3}$ Thus, in addition to energy balance transition, the Tarahumara's active lifestyles could be responsible for their high susceptibility to OA.

We respect the great contributions of the authors and we would also be very interested in the authors' response to these issues.

\section{Yang Yu ๑ , Shitao Lu, Jianzhong Xu}

Department of Orthopaedics, Zhengzhou University First Affiliated Hospital, Zhengzhou, Henan, China

Correspondence to Dr Jianzhong Xu, Department of Orthopaedics, Zhengzhou University First Affiliated Hospital, Zhengzhou, China; 13523520912@163.com

Contributors YY: concept, writing; SL: concept; JX: concept, revising.

Funding The authors have not declared a specific grant for this research from any funding agency in the public, commercial or not-for-profit sectors.

Competing interests None declared.

Patient and public involvement Patients and/or the public were not involved in the design, or conduct, or reporting, or dissemination plans of this research.

Patient consent for publication Not required.

Provenance and peer review Not commissioned; internally peer reviewed.

(C) Author(s) (or their employer(s)) 2020. No commercial re-use. See rights and permissions. Published by BMJ.

\section{Check for updates}

To cite Yu Y, Lu S, Xu J. Ann Rheum Dis Epub ahead of print: [please include Day Month Year]. doi:10.1136/annrheumdis-2020-217465

Received 31 March 2020

Accepted 1 April 2020

\section{Sinked}

- https://doi.org/10.1136/annrheumdis-2020-217484

Ann Rheum Dis 2020;0:1. doi:10.1136/annrheumdis-2020-217465

ORCID iD

Yang Yu http://orcid.org/0000-0003-3376-2338

\section{REFERENCES}

1 Wallace IJ, Felson DT, Worthington S, et al. Knee osteoarthritis risk in non-industrial societies undergoing an energy balance transition: evidence from the Indigenous Tarahumara of Mexico. Ann Rheum Dis 2019;78:1693-8.

2 Cross M, Smith E, Hoy D, et al. The global burden of hip and knee osteoarthritis: estimates from the global burden of disease 2010 study. Ann Rheum Dis 2014;73:1323-30.

3 Visser AW, de Mutsert R, le Cessie $S$, et al. The relative contribution of mechanical stress and systemic processes in different types of osteoarthritis: the Neo study. Ann Rheum Dis 2015;74:1842-7. 